\title{
NUTRITIONAL DEFICIENCIES AND CHILDREN'S BEHAVIOUR AND MENTAL DEVELOPMENT
}

\author{
DONALD T. SIMEON AND SALLY M. GRANTHAM-MCGREGOR
}

Tropical Metabolism Research Unit, University of the West Indies, Mona, St Andrew, Jamaica

\section{CONTENTS}

INTRODUCTION

IODINE DEFICIENCY . . . . . . . . . . . . . . . . . 2

IRON DEFICIENCY

INTERVENTION WITH CHILDREN UNDER 2 YEARS OF AGE . . . . . 3

Short-term treatment . . . . . . . . . . . . . . . . 3

Long-term treatment . . . . . . . . . . . . . . . . . . . 5

INTER VENTION WITH CHILDREN OVER 2 YEARS OF AGE . . . . . S

CONCLUSION . . . . . . . . . . . . . . . . . . . . . 7

SHORT-TERM FOOD DEPRIVATION . $\quad$. $\quad$. $\quad$. . . . . . . . . $\quad$. 8

MISSING BREAKFAST STUDIES . . . . . . . . . . . . . . . . 8

MECHANISM . . . . . . . . . . . . . . . . . . 9

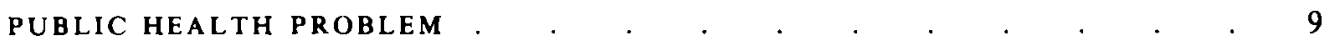

CONCLUSION . . . . . . . . . . . . . . . . . . . . . . 10

PROTEIN-ENERGY MALNUTRITION (PEM) . . . . . . . . . . . $\quad 10$

ACUTE STAGE OF SEVERE PEM . . . . . . . . . . . . . . . . . 10

LONG-TERM EFFECTS OF SEVERE PEM . . . . . . . . . . 11

Studies with matched controls . . . . . . . . . . . . . . . . . . . 11

Studies with sibling controls . . . . . . . . . . . . . . . 12

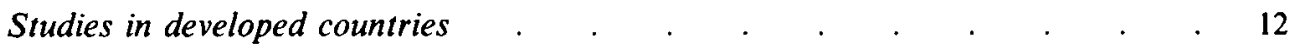

Rehabilitation from severe PEM . . . . . . . . . . . . . . 12

Comments on studies . . . . . . . . . . . . . . . . . . . . . . . 13

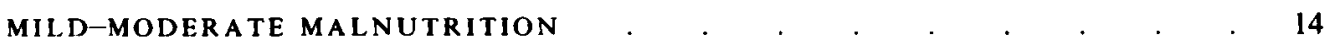

Observational studies . . . . . . . . . . . . . . . . . . . . . 14

Supplementation studies in developed countries . . . . . . . . . . . . $\quad$. 15

Supplementation studies in developing countries . . . . . . . . . . . . . 15

Preventive studies . . . . . . . . . . . . . . . . . . 15

Supplementation studies with undernourished children . . . . . . . 16

Comments on supplementation studies . . . . . . . . . . . . . . 17

Long-term effects of supplementation . . . . . . . . . . . . . . . . .

MECHANISM

CONCLUSIONS $\quad . \quad$.

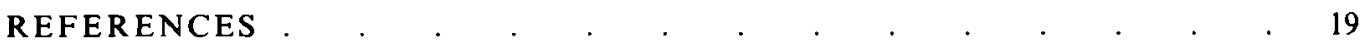




\section{INTRODUCTION}

The present review will consider the effects of nutritional deficiencies on behaviour and mental development in children. Although most research has been conducted on protein-energy malnutrition (PEM), recently there has been increasing interest in iron and iodine deficiencies, and short-term food deprivation. We will therefore briefly discuss these latter three topics, then focus in more detail on PEM. We will not cover the substantial body of research on animals.

There are some problems common to all these conditions. A child's mental development is affected by many different biological and psychological factors which range from facilitative to non-facilitative. Nutritional deficiencies inevitably occur in poor sociocultural and economic circumstances which themselves may have a detrimental effect on mental development. These effects are difficult to separate from those of undernutrition. Finding an association between poor development and undernutrition is, therefore, insufficient evidence to infer a causal relationship, and studies with experimental designs are necessary.

Measuring behaviour and mental development is also a problem. The validity of tests is doubtful in countries where there are no standardized indigenous tests (Pollitt $\&$ Thomson, 1977). Global measures such as developmental assessments and IQ tests have been used most frequently, but may not be sensitive to the subtle changes expected from nutritional deficits (Horowitz, 1989).

The duration and severity of the nutrient deficiency, the presence of multiple deficiencies, and the stage of development of the child may all modify the effects on his/her development. Further, it is likely that the quality of the social background would also modify the behavioural effects.

\section{IODINE DEFICIENCY}

It is estimated that 800 million people are at risk of I deficiency in Asia, Africa and Latin America (Hetzel, 1987). The term I-deficiency disorders (IDD), introduced by Hetzel (1983), is now used to describe the range of defects that are caused by this deficiency. These are described at length by Stanbury (1987) and include goitre, endemic cretinism, neuromotor delays, deaf-mutism and an increase in pre- and post-natal mortality. Severe deficiency during pregnancy results in deficits in fetal brain maturation and produces cretinism. There are two types of cretinism; neurological and myxoedematous. The symptoms of the former include mental retardation, spastic displegia and deaf-mutism, while those of myxoedematous cretinism include mental retardation and dwarfism.

There is also evidence that maternal I deficiency may result in an impairment of psychomotor development in children who do not suffer from overt cretinism. A clinical trial was conducted in Papua New Guinea in which I supplements were given to alternate families in five villages (Connolly et al. 1979). Of the 208 children who were born to mothers in the study, fourteen were cretins and of these thirteen were born to control mothers. The other children of the treated mothers performed better than those of the controls in tests of motor ability. Using a less efficient study design, pregnant women in a village in Ecuador were given I supplements and their children were compared with those from a nearby village (Fierro-Benitez et al. 1986). When the children were aged between 8 and 15 years, those from the treated village were found to have better school achievement levels and psychomotor development than those of the control village.

Bleichrodt et al. (1987) carried out two studies with a similar design in villages of comparable socio-economic conditions. The inhabitants of one of the villages were I- 
deficient while those of the other were not. These studies were conducted in Indonesia and Spain, and deficits in mental and motor development were found to be associated with I deficiency in both studies.

Although I deficiency during pregnancy has been found to affect development, it is not clear whether supplements given to I-deficient children are effective. A clinical trial was conducted in Bolivia in which $220 \mathrm{I}$-deficient children, aged 5-12 years, were randomly assigned to groups that received either I or a placebo (Bautista et al. 1982). No effect was found in the children's development or in school grades. However, there was an unexplained increase in the I intake of the control children which may have confounded any treatment effects.

I deficiency is a major public health problem. Not only is it one of the most prevalent nutrient deficiencies but its effects are drastic. It is estimated that there are over 190 million persons suffering from goitre and 3.15 million cretins due to I deficiency. The technology for its treatment is well-known and relatively simple. The use of iodized salt and iodized oil by injection or by mouth is very effective (Hetzel, 1987). However, before the problem can be effectively eradicated, there is a need for a political will to implement the programmes.

\section{IRON DEFICIENCY}

Fe deficiency is extremely prevalent globally. It is the commonest cause of anaemia, and anaemia is estimated to occur in $46-51 \%$ of children in less developed regions and $7-12 \%$ in more developed regions (DeMaeyer \& Adiels-Tegman, 1985). In adults, Fe deficiency affects work capacity and work productivity (Scrimshaw, 1984). Many studies have demonstrated that poor levels of development, cognitive function, and behavioural differences in children were associated with Fe deficiency. However, as in most research on nutrition and behaviour, this association is hopelessly confounded by poor social circumstances.

Over the last decade there have been an increasing number of experimental studies with Fe-deficient children in which the effects of Fe treatment were investigated. The more recent studies were discussed at a World Health Organization meeting (Pollitt et al. 1989a).

The studies presented at that meeting, and previous ones, which had pre- and posttreatment measures with matched controls or random assignment to treatment and placebo groups, are listed in Tables 1 and 2. Studies of marginally Fe-deficient, non-anaemic children have been omitted. They have produced inconsistent and generally negative results. The definition of Fe deficiency is problematical and it is generally accepted that at least two blood Fe indices should be abnormal (Fairchild et al. 1989).

\section{INTERVENTION WITH CHILDREN UNDER 2 YEARS OF AGE}

Seven reports were found which involved children under 24 months of age (Table 1). The results of the four studies, in which the initial performance of anaemic and non-anaemic groups was compared, indicated that the anaemic infants' performance was worse, confirming the association between Fe deficiency and poor mental development.

\section{Short-term treatment}

No benefit to children's developmental levels was found after short-term treatment of less than 2 weeks in three studies: in Guatemala (Lozoff et al. 1982), Costa Rica (Lozoff et al. 1987) and Chile (Walter et al. 1989). In the USA, Oski \& Honig (1978) studied twentyfour anaemic infants randomly assigned to treatment or placebo groups for 1 week. 
Table 1. Intervention studies of iron treatment with Fe-deficient anaemic children under 2 years of age

\begin{tabular}{|c|c|c|c|}
\hline Study & Design & Treatment & Results \\
\hline $\begin{array}{l}\text { Oski \& Honig } \\
\text { (1978) USA }\end{array}$ & $\begin{array}{l}\text { Twenty-four anaemic infants, } \\
\text { aged } 9.26 \text { months; random } \\
\text { assignment to treatment or } \\
\text { placebo groups }\end{array}$ & $\begin{array}{l}\text { Intramuscular (IM) } \\
\text { Fe; tested } 7 \text { d later }\end{array}$ & $\begin{array}{l}\text { MDI significantly increased in } \\
\text { treated group; change not } \\
\text { significantly different between } \\
\text { groups; motor scores not } \\
\text { different }\end{array}$ \\
\hline $\begin{array}{l}\text { Lozoff et al. } \\
\text { (1982) Guatemala }\end{array}$ & $\begin{array}{l}\text { Infants aged 6-24 months, } \\
\text { twenty-eight anaemic and } \\
\text { forty non-anaemic; randomly } \\
\text { assigned to treatment or } \\
\text { placebo groups }\end{array}$ & $7 \mathrm{~d}$ oral $\mathrm{Fe}$ & $\begin{array}{l}\text { Initially anaemic group had } \\
\text { lower MDI scores; no } \\
\text { treatment effect }\end{array}$ \\
\hline $\begin{array}{l}\text { Walter et al. } \\
\text { (1983) Chile }\end{array}$ & $\begin{array}{l}\text { Infants aged } 15 \text { months, twelve } \\
\text { non-anaemic controls, ten Fe- } \\
\text { deficient anaemic; all received } \\
\text { Fe treatment }\end{array}$ & Il d oral Fe & $\begin{array}{l}\text { Initially MDI scores lower and } \\
\text { children more unhappy in } \\
\text { anaemic group; anaemic } \\
\text { group improved significantly } \\
\text { more than controls in MDI }\end{array}$ \\
\hline $\begin{array}{l}\text { Aukett et al. } \\
\text { (1986) UK }\end{array}$ & $\begin{array}{l}\text { Ninety-seven anaemic children } \\
\text { aged } 17-19 \text { months; randomly } \\
\text { assigned to treatment or } \\
\text { placebo groups }\end{array}$ & $\begin{array}{l}\text { Oral } F e \text { and } \\
\text { vitamin } C \text { for } 2 \\
\text { months; placebo } \\
\text { was vitamin } C\end{array}$ & $\begin{array}{l}\text { Mean change in development } \\
\text { not significantly different; } \\
\text { more treated children } \\
\text { achieved normal rate of } \\
\text { development }\end{array}$ \\
\hline \multirow[t]{2}{*}{$\begin{array}{l}\text { Lozoff et al. } \\
\text { (1987) Costa Rica }\end{array}$} & $\begin{array}{l}\text { (1) Children aged } 12-24 \\
\text { months; fifty-two anaemic, } \\
\text { thirty-five non-anaemic; } \\
\text { random assignment to } \\
\text { treatment or placebo groups }\end{array}$ & $\begin{array}{l}\text { Oral or IM Fe for } \\
1 \text { week }\end{array}$ & $\begin{array}{l}\text { Initially anaemic group had } \\
\text { lower MDI and PDI scores; } \\
\text { no treatment effect after } 7 \mathrm{~d}\end{array}$ \\
\hline & $\begin{array}{l}\text { (2) Children from study no. } 1 \text {, } \\
\text { after the } 1 \text {-week Bayley test; } \\
\text { all anaemic group treated, } \\
\text { non-anaemic given placebo }\end{array}$ & $\begin{array}{l}\text { Oral Fe for } 12 \\
\text { weeks }\end{array}$ & $\begin{array}{l}\text { Anaemic children who had } \\
\text { complete Fe status recovery } \\
\text { after } 3 \text { months not } \\
\text { significantly different from } \\
\text { non-anaemic MDI and PDI } \\
\text { at } 15 \text { months; anaemic group } \\
\text { with partial recovery still had } \\
\text { significantly lower scores }\end{array}$ \\
\hline $\begin{array}{l}\text { Heywood et al. } \\
\text { (1989) Papua } \\
\text { New Guinea }\end{array}$ & $\begin{array}{l}\text { Ninety-six children aged } 2 \\
\text { months from longitudinal } \\
\text { cohort of bitths, matched for } \\
\text { sex, birth weight; random } \\
\text { assignment to treatment or } \\
\text { placebo groups; all checked } \\
\text { for malaria parasites }\end{array}$ & $\begin{array}{l}\text { IM Fe at } 2 \text { months; } \\
\text { tested at } 12 \\
\text { months }\end{array}$ & $\begin{array}{l}\text { Longer fixation time on test of } \\
\text { habituation in treated } \\
\text { children; interaction effect } \\
\text { with parasitaemia; no effect } \\
\text { on habituation or } \\
\text { dishabituation }\end{array}$ \\
\hline \multirow[t]{3}{*}{$\begin{array}{l}\text { Walter et al. } \\
\text { (1989) Chile }\end{array}$} & $\begin{array}{l}\text { (1) } 196 \text { infants stratified by } \\
\text { breast-feeding; randomly } \\
\text { assigned at } 3 \text { months to forti- } \\
\text { fied or non-fortified feeding; } \\
\text { no baseline measures }\end{array}$ & $\begin{array}{l}\text { Fe fortified food } \\
\text { from } 3 \text { to } 12 \\
\text { months; tested at } \\
12 \text { months }\end{array}$ & $\begin{array}{l}\text { Groups pooled, anaemic } \\
\text { children had lower MDI and } \\
\text { PDI at } 12 \text { months }\end{array}$ \\
\hline & $\begin{array}{l}\text { (2) Thirty-nine anaemics and } \\
\text { thirty non-anaemics from } \\
\text { pooled group at } 12 \text { months; } \\
\text { randomly assigned to } \\
\text { treatment or placebo groups }\end{array}$ & Oral $\mathrm{Fe}$ for $10 \mathrm{~d}$ & $\begin{array}{l}\text { No treatment effect on MDI or } \\
\text { PDI }\end{array}$ \\
\hline & $\begin{array}{l}\text { (3) All children from study no. } \\
2 \text { given Fe treatment }\end{array}$ & $\begin{array}{l}\text { Oral Fe from } 3 \\
\text { months }\end{array}$ & $\begin{array}{l}\text { No difference in change in } \\
\text { MDI or PDI between } \\
\text { anaemic and control groups }\end{array}$ \\
\hline
\end{tabular}

MDI, Mental development index of the Bayley test; PDI, Psycho-motor development index of the Bayley test. 
Although the treated group improved significantly on the Bayley scales of mental development (Hurwitz, 1984), the improvement was not significantly greater than that of the placebo group. However, these groups were probably too small to obtain conclusive findings. Walter et al. (1983) found a significant improvement in treated anaemic children after $11 \mathrm{~d}$, but there was no placebo anaemic group, therefore causal inferences cannot be made (Fairchild et al. 1989).

\section{Long-term treatment}

Treatment lasting longer than 2 weeks produced somewhat more positive results. Aukett et al. (1986) in England found no significant difference after 2 months of treatment between anaemic groups treated with $\mathrm{Fe}$ or placebo in the number of new items acquired on the Denver mental development test. However, more Fe-treated than placebo-treated children achieved a normal rate of development.

Both Heywood et al. (1989) in Papua New Guinea, and Walter et al. (1989) in Chile ran preventive trials in which children were randomly assigned to $\mathrm{Fe}$ treatment or placebo at 2 and 3 months of age respectively. In both studies, a significant difference between the treatment and placebo groups was found at 12 months of age. Walter et al. (1989) used the Bayley development test whereas Heywood et al. (1989) used a test of habituation. The children treated with $\mathrm{Fe}$ had longer fixation times on the latter test. Unfortunately, the meaning of this finding in this population is unknown, and no effect was found on habituation or dishabituation.

In two studies, one in Costa Rica (Lozoff et al. 1987) and the other in Chile (Walter et al. 1989), anaemic children were treated for 3 months. However, the studies were not true clinical trials. In both, all the anaemic children were treated. In one study no improvement with Fe treatment was found (Walter et al. 1989), while in the other only those children who had completely normal levels in all blood Fe indices after treatment caught up to the nonanaemic group. The remaining anaemic children who were treated showed no improvement.

\section{INTERVENTION WITH CHILDREN OVER 2 YEARS OF AGE}

Nine reports of twelve studies of the effects of giving Fe to children over 2 years of age are shown in Table 2. Two studies found no significant benefits in behaviour. In one, which was conducted in the USA (Deinard et al. 1986), all anaemic children were treated and they were compared with matched controls. The other study, which was conducted in Thailand, was a true clinical trial and school achievement was the outcome measured (Pollitt $e t$ al. $1989 \mathrm{~b}$ ). Intervention lasted 16 weeks which may not have been long enough to produce improvements.

In the remaining ten studies benefits from $\mathrm{Fe}$ treatment were claimed. Three did not have random assignment to treatment or placebo (Pollitt et al. 1983a, 1986; Seshadri \& Gopaldas, 1989 (study no. 1)). In another study folic acid and Fe were given, and this produced benefits to the children's IQ scores (Seshadri \& Gopaldas, 1989 (study no. 2)). However, in six studies there was random assignment to treatment or placebo groups; three in Indonesia (Soemantri et al. 1985; Soemantri, 1989; Soewondo et al. 1989), one in Egypt (Pollitt et al. 1985) and two in India (Seshadri \& Gopaldas, 1989). These designs were robust, and treatment lasted for 2 months or more. Outcome variables included school achievement in two studies (Soemantri et al. 1985; Soemantri, 1989) and cognitive function tests in four studies (Seshadri \& Gopaldas, 1989 (study nos 3 and 4); Soewondo et al. 1989; Pollitt et al. 1985). 
Table 2. Intervention studies of iron treatment with Fe-deficient anaemic preschool and school-aged children

\begin{tabular}{|c|c|c|c|}
\hline Study & Design & Treatment & Results \\
\hline $\begin{array}{l}\text { Pollitt et al. } \\
(1983 a) \text { USA }\end{array}$ & $\begin{array}{l}\text { Children aged } 3 \text { to } 6 \text { years; } \\
\text { fifteen anaemic, fifteen non- } \\
\text { anaemic; anaemic group } \\
\text { treated }\end{array}$ & $\begin{array}{l}\text { Oral } \mathrm{Fe} \text { for } 3 \\
\text { months }\end{array}$ & $\begin{array}{l}\text { Initially anaemic group worse } \\
\text { in three tests of discrimination } \\
\text { learning; at end, anaemic } \\
\text { group caught up in all tests }\end{array}$ \\
\hline $\begin{array}{l}\text { Soemantri et al. } \\
\text { (1985) Indonesia }\end{array}$ & $\begin{array}{l}\text { Primary school children, } \\
\text { average age } 10.8 \text { years, } \\
\text { seventy-eight anaemic, forty- } \\
\text { one non-anaemic; both } \\
\text { groups assigned to treatment } \\
\text { or placebo; all treated for } \\
\text { hookworm }\end{array}$ & 3 months oral $\mathrm{Fe}$ & $\begin{array}{l}\text { Initially, school performance } \\
\text { worse in anaemic group; } \\
\text { treated anaemic group } \\
\text { improved significantly more } \\
\text { than anaemic placebo group }\end{array}$ \\
\hline $\begin{array}{l}\text { Pollitt et al. } \\
\text { (1985) Egypt }\end{array}$ & $\begin{array}{l}\text { Mean age } 9.5 \text { years; twenty- } \\
\text { eight anaemic, forty non- } \\
\text { anaemic; both groups } \\
\text { assigned to treatment or } \\
\text { placebo }\end{array}$ & 4 months oral $\mathrm{Fe}$ & $\begin{array}{l}\text { Initially, efficiency of problem } \\
\text { solving worse in anaemic } \\
\text { group; at end, anaemic } \\
\text { treated group significantly } \\
\text { better than anaemic placebo } \\
\text { group and same as non- } \\
\text { anaemics }\end{array}$ \\
\hline $\begin{array}{l}\text { Pollitt et al. } \\
\text { (1986) Guatemala }\end{array}$ & $\begin{array}{l}\text { Children aged } 3-6 \text { years; } \\
\text { twenty-five anaemic, twenty- } \\
\text { five non-anaemic; both } \\
\text { groups treated }\end{array}$ & $12 \mathrm{~d}$ oral $\mathrm{Fe}$ & $\begin{array}{l}\text { Initially, anaemic group } \\
\text { significantly worse in } \\
\text { discriminatory and oddity } \\
\text { learning; improved } \\
\text { significantly with treatment in } \\
\text { discriminatory learning, and } \\
\text { caught up to controls; no } \\
\text { treatment effects on oddity } \\
\text { learning }\end{array}$ \\
\hline $\begin{array}{l}\text { Deinard et al. } \\
\text { (1986) USA }\end{array}$ & $\begin{array}{l}\text { Children aged } 18-60 \text { months; } \\
\text { twenty-five anaemics, two } \\
\text { control groups matched for } \\
\text { maternal education and } \\
\text { baseline DQ; all anaemics } \\
\text { treated, all controls given a } \\
\text { placebo }\end{array}$ & 6 months oral $\mathrm{Fe}$ & $\begin{array}{l}\text { No initial differences between } \\
\text { anaemics and controls in } \\
\text { mental development; no } \\
\text { treatment effect }\end{array}$ \\
\hline \multirow[t]{3}{*}{$\begin{array}{l}\text { Seshadri \& } \\
\text { Gopaldas } \\
\text { (1989) India }\end{array}$} & $\begin{array}{l}\text { (1) Ninety-four schoolchildren } \\
\text { aged 5-8 years randomly } \\
\text { assigned to treatment or no } \\
\text { treatment groups before } \mathrm{Fe} \\
\text { status estimation }\end{array}$ & $\begin{array}{l}\text { Oral } \mathrm{Fe} \text { and folic } \\
\text { acid for } 3 \text { months }\end{array}$ & $\begin{array}{l}\text { Initially anaemic had lower IQ } \\
\text { scores than non-anaemic only } \\
\text { at age } 8 \text { years; treated group } \\
\text { improved significantly more } \\
\text { than non-treated group }\end{array}$ \\
\hline & $\begin{array}{l}\text { (2) Fourteen pairs of anaemic } \\
\text { boys aged } 5-6 \text { years matched } \\
\text { for weight and height, IQ } \\
\text { scores, SES; random } \\
\text { assignment to treatment or } \\
\text { placebo; both groups given } \\
\text { mebendazole }\end{array}$ & $\begin{array}{l}\text { Oral } F e \text { and folic } \\
\text { acid } 3 \text { months }\end{array}$ & $\begin{array}{l}\text { Both groups showed significant } \\
\text { improvement in IQ; at end, } \\
\text { treated group significantly } \\
\text { better; no control for small } \\
\text { initial differences }\end{array}$ \\
\hline & $\begin{array}{l}\text { (3) Sixteen sets of three school } \\
\text { boys } 8-15 \text { years matched for } \\
\text { Hb, age, cognitive function } \\
\text { test scores; randomly assigned } \\
\text { to three groups }\end{array}$ & $\begin{array}{l}\text { Oral Fe } 3 \text { months, } \\
30 \mathrm{mg} \text { or } 40 \mathrm{mg} / \mathrm{d} \\
\text { or placebo }\end{array}$ & $\begin{array}{l}\text { Children receiving } 40 \mathrm{mg} \text { or } \\
30 \mathrm{mg} \text { significantly improved } \\
\text { in tests of digit span, visual } \\
\text { recall, and clerical task; } 40 \mathrm{mg} \\
\text { groups also improved in } \\
\text { mazes; only anaemic children } \\
\text { improved }\end{array}$ \\
\hline
\end{tabular}


Table 2 (cont.)

\begin{tabular}{|c|c|c|c|}
\hline Study & Design & Treatment & Results \\
\hline & $\begin{array}{l}\text { (4) Poor school girls aged } 8-15 \\
\text { years; sixty-five pairs matched } \\
\text { for age, } \mathrm{Hb} \text { and test scores; } \\
\text { randomly assigned to } \\
\text { treatment or placebo }\end{array}$ & $\begin{array}{l}60 \text { mg Fe daily for } \\
3 \text { months; tested } \\
\text { at } 4 \text { months and } \\
\text { re-treated for } 3 \\
\text { months }\end{array}$ & $\begin{array}{l}\text { No initial difference between } \\
\text { anaemic and non-anaemic } \\
\text { children in visual recall, digit } \\
\text { span, mazes and clerical task; } \\
\text { at end, treated anaemic } \\
\text { children significantly better in } \\
\text { clerical tasks, mazes and } \\
\text { overall test than placebo } \\
\text { anaemics; treated non- } \\
\text { anaemics significantly better } \\
\text { than placebos in mazes }\end{array}$ \\
\hline $\begin{array}{l}\text { Soewando et al. } \\
\text { (1989) Indonesia }\end{array}$ & $\begin{array}{l}\text { Seventy non-anaemics, and } \\
\text { forty-nine anaemics mean age } \\
54 \text { months, both groups } \\
\text { randomly assigned to } \\
\text { treatment or placebo groups }\end{array}$ & 8 weeks oral $\mathrm{Fe}$ & $\begin{array}{l}\text { Initially non-anaemics better } \\
\text { than anaemics in oddity learn- } \\
\text { ing and easy discrimination } \\
\text { learning; significant treatment } \\
v . \text { Fe status effect ; treated } \\
\text { anaemic group improved } \\
\text { more than placebo anaemic } \\
\text { group in two tests of oddity } \\
\text { learning and one of } \\
\text { discrimination learning (i.e. } \\
\text { three out of nine tests) }\end{array}$ \\
\hline $\begin{array}{l}\text { Pollitt ef al. } \\
(1989 \mathrm{~b}) \text { Thailand }\end{array}$ & $\begin{array}{l}\text { 9-11-year-old school children } \\
\text { randomly assigned to } \\
\text { treatment or placebo; } 1775 \\
\text { children completed study; } \\
101 \text { anaemic and } 1210 \text { non- } \\
\text { anaemic all treated with } \\
\text { albendazole }\end{array}$ & $\begin{array}{l}\text { Oral Fe for } 10 \\
\text { weeks }\end{array}$ & $\begin{array}{l}\text { Initially anaemic group had } \\
\text { lower IQ and school } \\
\text { achievement scores in Thai; } \\
\text { no treatment effects; all } \\
\text { groups improved in IQ. Thai } \\
\text { and arithmetic }\end{array}$ \\
\hline $\begin{array}{l}\text { Soemantri } \\
\text { (1989) Indonesia }\end{array}$ & $\begin{array}{l}\text { Fifty-eight anaemics and } \\
\text { seventy-two non-anaemics } \\
\text { aged } 8-11.6 \text { years, over } 80 \% \\
\text { weight-for-age; both groups } \\
\text { randomly assigned to } \\
\text { treatment or placebo; treated } \\
\text { for ancylostomiasis }\end{array}$ & $\begin{array}{l}\text { Oral } \mathrm{Fe} \text { for } 3 \\
\text { months; tested } \\
\text { after } 6 \text { months }\end{array}$ & $\begin{array}{l}\text { No significant change in IQ; } \\
\text { anaemic treated group } \\
\text { improved more than anaemic } \\
\text { placebo group in } \\
\text { mathematics, biology, } \\
\text { language and social science } \\
\text { at } 6 \text { months; no statistics } \\
\text { presented }\end{array}$ \\
\hline
\end{tabular}

Hb, haemoglobin; SES, Socio-Economic Status.

\section{CONCLUSION}

The evidence is strong that children over 2 years of age with Fe-deficiency anaemia in developing countries benefit from Fe treatment in some cognitive functions and school achievement. However, the findings are not totally consistent and the circumstances in which improvements occur are not clear. In contrast, there is little clear evidence from welldesigned clinical trials, with long- or short-term treatment, of a benefit to anaemic younger children. One exception is when Fe therapy is instituted prophylactically in the first 3 months of age.

Which cognitive functions are affected by Fe deficiency is not clear, and lack of appropriate tests of cognitive functions in infants may be responsible for the negative findings in this age-range (Pollitt, 1989). It is likely that developmental levels in children take a long time to respond to Fe treatment. This may explain the positive response found in the long-term prophylactic studies compared with the failure of response in studies lasting less time. 


\section{SHORT-TERM FOOD DEPRIVATION}

Short-term food deprivation affects children in both developing and developed countries. However, it is more likely to be due to economic necessity in the former. Most studies on the topic have involved investigations of the effects of missing breakfast. The most appropriate studies have cross-over designs in which subjects are compared with themselves with and without breakfast (Kruesi \& Rapoport, 1986).

\section{MISSING BREAKFAST STUDIES}

Seven reports were identified. In the earliest, which came from the USA, Tuttle et al. (1954) carried out two studies with small groups of 12-14-year-old boys. In one study, seven boys showed a reduction in work capacity on bicycle ergonometry when breakfast was omitted, but no effect on neuromuscular tremor or reaction time. Teachers also reported that the children deteriorated in classroom behaviour; however, it is uncertain how this was assessed and whether the teachers were blind to the treatment groups. The findings were replicated in the second study with eighteen children, except that classroom behaviour was not examined.

Dickie \& Bender (1982) conducted two studies of fifty-five and fifty-three students respectively aged 16-17 years, from English boarding schools. In both studies, no effect was found with the omission of breakfast. Tests of arithmetic and short-term memory were used in one study and tests of attention in the other. A second report of no effect concerned fifty schoolchildren aged 6-8 years in India (Upadhyay et al. 1988). The children were tested either at home or at school. Missing breakfast had no effect on short-term memory, arithmetic, reaction time and free recall serial learning.

Three studies of similar design, which were carefully controlled, were reported by Pollitt et al. $(1981,1983 b)$ and Simeon \& Grantham-McGregor (1989). Children aged between 9 and 11 years old were admitted to hospital overnight on two occasions. Half the children were randomly assigned to receive breakfast on the first admission while the others did not. The treatment was reversed on the second admission. The children had a standard dinner on the night of admission and were given a battery of cognitive function tests at 11.00 hours the next morning. Two tests were used in all three studies, matching familiar figures test (MFFT) and Hagen's central incidental task (HCI). The MFFT is a test of speed and accuracy of problem solving while the $\mathrm{HCI}$ measures short-term recall (central) and attention to irrelevant information (incidental).

In the first of two studies in the USA (Pollitt et al. 1981), the children's performance improved on missing breakfast in the central task of the $\mathrm{HCI}$ while the incidental task was not affected. The children with lower IQ made more errors in the MFFT. In a replication of this study (Pollitt et al. $1983 \mathrm{~b}$ ), all children missing breakfast deteriorated in MFFT and the incidental task of the $\mathrm{HCI}$ while performance on the central task was not affected. In the first study, a test of continuous performance was also used but was not affected by the omission of breakfast.

The third study was conducted in Jamaica (Simeon \& Grantham-McGregor, 1989). Effects were compared of missing breakfast in thirty stunted (low height-for-age) with matched non-stunted children and thirty children who had been severely malnourished in early childhood. The hypothesis was that undernourished children were more likely to be adversely affected by missing breakfast. Several other tests of cognitive function were added to the MFFT and the HCI. Both malnourished groups behaved similarly on missing breakfast. They were detrimentally affected in fluency and coding, whereas the controls improved in arithmetic and the efficiency of problem solving. In addition, children who had 
low weights-for-height (i.e. were wasted) from any group were detrimentally affected in short-term memory whereas the non-wasted children were not. It was clear that undernourished children whether stunted, wasted or previously severely malnourished were more likely to be detrimentally affected than adequately nourished children by short-term food deprivation.

The final study which was conducted in the USA included only ten children (Conners \& Blouin, 1983) and details were not reported. This was the only study in which children were tested at different times during the morning and measures of central nervous system (visual evoked potentials) and autonomic nervous system functions (cardiac response to stimuli) were taken. The omission of breakfast was accompanied by a deterioration in both these measures and in arithmetic which became worse with the duration of the fast.

\section{MECHANISM}

There is little information to provide evidence for the mechanism linking missing meals to cognitive function changes. One could speculate that the metabolic changes induced by fasting increase arousal levels (Pollitt $e t$ al. 1981). In the only study with measurements of autonomic nervous function, changes were found in the cardiac response (Conners \& Blouin, 1983). The arousal level has an 'inverted- $U$ ' curve relationship with performance, and optimal performance occurs at the peak of the curve. The curve varies with different tasks (Hebb, 1972) and in different types of subjects (Eysenck, 1976). Children of different ages, intelligence and social backgrounds may respond differently in arousal levels to a similar stressor. A further possibility is that metabolic changes due to fasting produce changes in neurotransmitter precursors which affect behaviour (Wurtman, 1986).

There are some findings from rat studies which concur with the findings of the Jamaican study (Simeon \& Grantham-McGregor, 1989) that undernourished children were more vulnerable to hunger. Rats which were undernourished before weaning and then rehabilitated showed increased responsiveness to hunger (Barnes et al. 1968), thirst (Smart \& Dobbing, 1977), electric shocks and loud noises (Levitsky \& Barnes 1970). Levitsky \& Barnes (1970) suggested that the previously undernourished rats had a heightened autonomic response to aversive stimuli. It is possible that undernourished children may have altered metabolic or arousal responses to fasting. They may also appraise the situation as a greater threat.

\section{PUBLIC HEALTH PROBLEM}

If children are exposed to repeated episodes of missing breakfast, then the transient changes in cognitive function could lead to more long-lasting delays in school achievement and development. There is some evidence from studies of the determinants of school achievement in developing countries that low dietary intakes (Wilson, 1981), usually being hungry (Popkin \& Lim-Ybanez, 1982), and not eating breakfast (N. Clarke, personal communication) are significant determinants of poor school achievement. Similarly food intake was a significant predictor of cognitive function in undernourished children in Kenya (Sigman et al. 1990).

In several studies, short-term improvement in schoolchildren's behaviour occurred following snacks and drinks (Laird et al. 1931 ; Keister, 1950; Benton et al. 1987); however, this was not found in all studies (Dwyer et al. 1972). School feeding programmes have generally been inadequately evaluated. They frequently lack baseline measures and have no suitable control groups (Levinger, 1986). In Jamaica (Powell et al. 1983) an improvement was found in arithmetic in a class of undernourished children who were given breakfast when compared with matched controls. In a recent study in the USA (Meyers et al. 1989), 
children who had breakfast at school improved more in school achievement than matched controls.

It is therefore likely that short-term food deprivation is an important public health problem. However, there is need for more research in the area in order to provide further bases for policy decisions and to understand the mechanism.

\section{CONCLUSION}

The findings from studies of missing breakfast in children are inconsistent. One reason for this may be that the changes in behaviour due to missing meals are subtle and only carefully controlled studies with sensitive, reliable tests would be likely to detect differences (Kruesi \& Rapoport, 1986). Different tests were used in many studies and this may account for some differences in findings. In a few studies the order of testing was not controlled. Further, dietary control cannot be certain where children were not supervised overnight. In some studies the previous meal was not standardized, and the duration of the fast varied between studies.

In those studies in which dietary control, study design and testing were most rigorous, differences were found (Pollitt et al. 1981, 1983b; Simeon \& Grantham-McGregor, 1989). However, even in these studies there were differences in the cognitive functions affected.

An explanation for these differences may lie in the findings of Simeon \& GranthamMcGregor (1989). It was clearly shown that undernourished children are more susceptible to the adverse effects of missing breakfast than adequately nourished ones. It is also possible that both biological and psychological differences in the children modify their response to missing meals.

\section{PROTEIN-ENERGY MALNUTRITION (PEM)}

PEM is a global term used for children with weights, heights or weight-for-height below certain standard cut-off points. It does not necessarily reflect aetiology because differing degrees and types of nutrient deficiencies may be present, not just protein and energy. Further, differing levels of infection may contribute to the condition. In general, most studies of PEM and mental development have used the term severe PEM for cases of kwashiorkor, marasmus and marasmic-kwashiorkor, and moderate malnutrition for weights below $80 \%$ of the expected value for age and sex (Wellcome Trust Working Party, 1970) or below $75 \%$ (Gomez et al. 1955).

It is only recently that studies have focused on height-for-age or weight-for-height (Waterlow, 1976). Height-for-age is more likely to reflect duration of undernutrition, although the precise aetiology is uncertain (Golden, 1988), while weight-for-height reflects recent nutritional experiences.

The prevalence of severe PEM ranges from 1 to $10 \%$ in developing countries, and moderate PEM from 7 to $60 \%$. It is estimated that 150 million children are suffering from PEM (Grant, 1990). The extent to which these children's development is affected is therefore of critical importance.

\section{ACUTE STAGE OF SEVERE PEM}

Studies of the behaviour of children during the acute episode have been reviewed elsewhere (Grantham-McGregor, 1984), Early studies had no controls for the effect of being in hospital on the children's behaviour. Severely malnourished children were reported to have 
very low developmental levels which showed some improvement with recovery (Cravioto \& Robles, 1965; Yatkin \& McLaren, 1970; Monckeberg, 1979). However, in a Jamaican study (Grantham-McGregor et al. 1987), they were compared with adequately nourished children who were in hospital suffering from other diseases. It was found that the developmental levels (DQ) of both groups improved similarly. The severely malnourished group began with a marked deficit compared with the controls and showed no sign of reducing their deficit. On recovery from the acute episode, they continued to have very low developmental levels.

In the same study, the severely malnourished group were more apathetic, inactive and explored less than the controls. This behaviour showed rapid improvement and following recovery there was no difference between the groups. The transient nature of the behavioural changes contrasts with that of the persistent developmental lag. The precise mechanism causing the behavioural change is unknown.

\section{LONG-TERM EFFECTS OF SEVERE PEM}

Most studies of PEM and mental development have concerned the long-term sequelae of school-aged children who suffered from severe malnutrition in early childhood.

In developing countries, severe PEM is confounded by a multitude of poor social circumstances (Grantham-McGregor, 1984). Research in this area is more difficult than with other nutrient deficiencies because experimental studies are not ethical with this degree of malnutrition. Several strategies have therefore been used to control for the effects of social background on development. Investigators have used carefully matched controls or siblings for comparison. In addition, they have measured an extensive number of factors in the children's environment which theoretically might affect their development and then controlled for them statistically. The long-term follow-up studies divided into those with matched controls and those with sibling controls will be reviewed.

\section{Studies with matched controls}

In six of the seven studies with reasonably well-matched controls, severe malnutrition was accompanied by deficits in development. Champakam et al. (1968) compared nineteen Indian children who were hospitalized for kwashiorkor with fifty matched controls when they were aged 8-11 years. The malnourished children performed worse in tests of neurosensory integration, abstract and verbal abilities and memory.

In Jamaica, seventy-four survivors of severe malnutrition were compared with controls between the ages of 6 and 10 years (Hertzig et al. 1972; Richardson et al. 1973). The malnourished children had lower IQ and school achievement levels than the controls. In addition, they had more behaviour problems. Also in Jamaica, seventeen severely malnourished children were followed prospectively from the acute episode and remained with lower IQ than a control group who were also in hospital, up to 6 years after returning home (Grantham-McGregor et al. 1987).

In Uganda, Hoorweg \& Stanfield (1976) investigated the effects of a previous episode of severe malnutrition in sixty children aged 11-17 years. They were found to have lower IQ and performed worse in tests of memory, incidental learning and motor development than controls. In Nigeria, Nwuga (1977) compared the mental functions of fifty-two previously severely malnourished children aged 9 and 10 years with controls. The malnourished children had lower IQ than the controls.

In a Barbadian study, 129 previously malnourished children were compared with controls between the ages of 5 and 11 years (Galler et al. 1983a,b, 1984a,b). The malnourished children had lower IQ and school achievement levels than the controls. They 
also had more behaviour problems and motor development delays. When the children were re-examined between the ages of 11 and 18 years they were still found to have lower IQ and motor delays than the controls (Galler et al. 1987a, b).

In South Africa (Bartel et al. 1978), no differences were found between thirty-one previously malnourished children, aged 6-12 years, and controls in motor development or grip strength. However, no tests of intelligence or cognitive function were used.

\section{Studies with sibling controls}

In four of the eight studies in which siblings were used as controls, the index children had lower levels of performance. In Mexico, thirty-seven previously severely malnourished children aged 5-13 years had lower IQ than their siblings but the difference was only significant in the boys (Birch et al. 1971).

In a Jamaican study described previously (Hertzig et al. 1972; Richardson et al. 1973), the index children had lower verbal but not performance scores on the Wechsler Intelligence Scale for Children (WISC) IQ test than their siblings. They also had more behaviour problems, but no difference was found in school achievement levels. In the Nigerian study previously described (Nwuga, 1977), the previously severely malnourished children had lower IQ than their siblings, while in India, Pereira et al. (1979) found that previously malnourished children had worse school grades.

In South Africa, Evans et al. (1971) found no difference in the IQ of forty survivors of early severe malnutrition and their siblings at age 9-14 years. However, they had lower scores on the Goodenough drawing test.

In three studies no difference was found between the index children and their siblings. Graham \& Adrianzen (1979) in Peru compared 110 index children aged 6-12 years with 188 siblings and found no effect on school performance. In South Africa, Bartel et al. (1978) found no difference in motor development or grip strength when thirty-one survivors of severe PEM were compared with their siblings. Also in South Africa, Moodie et al. (1980) found no difference in school attainment, employment status or social adjustment between previously severely malnourished children and siblings whom they had followed for 15 years.

\section{Studies in developed countries}

Investigators have attempted to separate the long-term effects of severe PEM from the confounding effects of continuing poor nutrition and socio-economic conditions by conducting studies in developed countries (Rush, 1984).

Several studies involved subjects who were moderately or severely malnourished in early childhood due to conditions such as cystic fibrosis and pyloric stenosis. In general, these children were less severely malnourished for shorter periods than those studied in developing countries and there were little or no deficits in mental development (Berglund \& Rabo, 1973; Lloyd-Still et al. 1974; Valman, 1974; Ellis \& Hill, 1975; Klein et al. 1975).

\section{Rehabilitation from severe PEM}

There is increasing evidence that children can improve in mental development if exposed to an enriched environment. Malnourished Korean children who were adopted by families in the USA before the age of 2 years had IQ and school achievement levels which were normal for North American children (Winick et al. 1975). However, the malnutrition may still have been important as there was a relationship between the children's performance and their levels of malnutrition at the time of adoption.

Psychosocial stimulation given to children while they were in hospital has been reported to produce only transient improvements in children's development (McLaren et al. 1973; 
Cravioto \& Arrieta, 1979). However, long-term stimulation resulted in improvements which were sustained for 3 years following cessation of treatment (Grantham-McGregor et al. 1987).

\section{Comments on studies}

A difficulty with almost all the studies is that there was no control for current dietary intake and nutritional status which may have contributed to the differences between the groups. Another problem in interpreting these findings is that all index children were in hospital during the acute episode. In only one (Grantham-McGregor et al. 1987) of the previously mentioned studies was there partial control for the effect of hospitalization.

There is also the problem with retrospective studies that the children may have been different before the onset of severe PEM. In only one study (Cravioto \& DeLicardie, 1972) were children examined from birth before the onset of severe malnutrition. In a cohort of births in a Mexican village, eighteen children who developed severe PEM had language development which was not different from matched controls before the episode. However, this is insufficient evidence to attribute equivalent development before onset of malnutrition in all studies.

Differences were somewhat more likely to be found between survivors of severe PEM and matched controls than with siblings. Further, the differences between index children and matched controls were more extensive. This is to be expected because although siblings may vary slightly from the index children in birth order and age, they are probably the best match for social background. It is impossible to match for all factors affecting mental development, and even with careful matching the controls tend to have worse social backgrounds (Richardson, 1974), and their homes have differences in the microenvironment (Cravioto \& DeLicardie, 1972).

The main problem with siblings is that they are highly likely to have been undernourished themselves. It may be that the only nutritional difference between the groups was that the index children had suffered from an acute episode of severe malnutrition and that both groups were exposed to long-term undernutrition. The relative contribution of long-term mild to moderate undernutrition and an acute episode of severe malnutrition to developmental level is unknown. However, in a Jamaican study of children suffering from severe PEM, height-for-age on admission to hospital predicted DQ on recovery whereas the presence of oedema or weight-for-height did not (Grantham-McGregor, 1982).

In another Jamaican study, children who had recently recovered from severe PEM had similar DQ to children matched for height-for-age, age and social background (GranthamMcGregor et al. 1989a). This suggested that height-for-age, which is thought to indicate duration of undernutrition, may be a more important predictor of $D Q$ than the severe episode. In the Ugandan study (Hoorweg \& Stanfield, 1976) signs of the acute episode such as oedema did not predict later IQ levels whereas weight deficit did. Unfortunately, height measurements were not reported.

The findings from studies in developed countries and adoption studies suggest that the quality of the social background at the time of the episode and following, as well as subsequent nutrition, may determine the effect of malnutrition. Research in rats has shown that the adverse effects of malnutrition on behaviour are reduced by increased stimulation (Levitsky, 1979). The concept of an interaction between the environment and PEM on their effects on development has been further developed by Pollitt (1987).

Many questions remain unanswered. It is not known whether the age of onset affects the outcome. Several studies compared children presenting before and after 6 months of age but findings were inconsistent. Also, there is little consistent evidence of a deficit in specific cognitive functions. The cognitive functions affected vary among studies. The behaviours 
affected imply that they are shy, withdrawn, less active, less sociable, emotionally immature, and have poor attention (Grantham-McGregor, 1984).

In conclusion, a causal relationship between severe malnutrition and poor mental development and behaviour problems cannot be established unequivocally from observational studies. However, the consistency of findings from different investigators in different countries suggests that the relationship is causal and when children return to impoverished environments they remain with poor levels of development at least through to adolescence. At present there is little information into adulthood. It would appear that marked improvement can occur with an enriched environment; however, it is not clear whether complete recovery occurs.

\section{MILD-MODERATE MALNUTRITION}

Mild to moderate PEM is much more prevalent than severe PEM; therefore if it has a detrimental effect on development it would have greater public health implications.

\section{Observational studies}

In several developing countries, observational studies of the relationship between mild to moderate PEM and mental development have been conducted.

In three studies of young children, after controlling for social background, nutritional status was found to predict mental development significantly. In Guatemala both weight and height predicted development (Lasky et al. 1981), while in Jamaica height-for-age was a significant predictor whereas weight-for-height was not (Powell \& Grantham-McGregor, 1985), and in Colombia height-for-age predicted the children's development (Christiansen et al. 1977). Monckeberg (1972) in Chile also found that malnourished children had lower levels of development but social background was not controlled.

Nutritional status of schoolchildren has also been found to be a significant predictor of their development or achievement levels, after controlling for social background. In the Philippines, weight-for-height was a significant predictor of school grades, but the effects of height-for-age were not examined (Popkin \& Lim-Ybanez, 1982). In four studies, the children's heights-for-age were significantly associated with their achievement levels whereas there was little or no association with weight-for-height. These studies were conducted in Nepal (Moock \& Leslie, 1986), Jamaica (Clarke et al. 1990), India (Agarwal et al. 1987), and the Philippines (Florencio, 1988). In Guatemala, Johnston et al. (1987) found an interaction between height-for-age and social background in the prediction of mental development. They did not examine the effects of weight-for-height.

Height-for-age was also found to be associated with school achievement in studies conducted in Jamaica (Powell \& Grantham-McGregor, 1980), in China (Jamison, 1986) and in Singapore (Chun, 1971), and with neurosensory integration in Mexico (Cravioto et al. 1966). However, there was no control for social background in these four studies.

Of the fifteen identified, there was only one report in which nutritional status was not found to be associated with development (Colombo et al. 1988). Overall, height-for-age was more consistently associated with development than was weight-for-height.

Due to the cross-sectional design of the previously described studies causation cannot be established between malnutrition and mental development. A more powerful method of demonstrating the effect on development is to compare children who received nutritional supplementation with those of non-supplemented controls in populations where malnutrition is endemic. 


\section{Supplementation studies in developed countries}

A few studies of supplementation and mental development have been described from developed countries. These have mostly been restricted to pregnancy. In Montreal, Canada, supplementation of pregnant women produced no measured benefits to their children's later school achievement compared with their siblings and matched controls (Pencharz et al. 1983). In Philadelphia, a high-protein supplement given to pregnant, lowincome women (Osofsky, 1975) did not benefit their offspring in the first week of life. However, activity was reduced and this could not be explained.

Rush et al (1980) in New York supplemented pregnant high-risk women in a randomized trial. At 12 months of age, the offspring showed no benefit on the Bayley development scores, object permanence or sophistication of play. Infants who received a high-protein supplement had significantly longer episodes of play, and habituated more rapidly to visual stimuli than the controls.

In Louisiana, twenty-one children whose mothers received a supplement from the third trimester of pregnancy, and were supplemented themselves for at least 1 year, were compared with their older siblings who had not received the supplement until after their first year (Hicks et al. 1982). At 6 years of age, the index children had significantly higher IQ scores than their 8-year-old siblings. Large differences were found in this study, but the groups differed in age and birth order.

Although the previously mentioned studies were conducted using low-income families, it is far from certain that the children would have been undernourished without supplementation. Studies in developing countries are therefore more appropriate to address the question of undernutrition and mental development.

\section{Supplementation studies in developing countries}

All these studies have been reviewed previously in detail (Grantham-McGregor, 1987). Some were preventive in that supplementation began in pregnancy, whereas others were remedial with supplements being given to undernourished children. Only studies with reasonably well-matched controls will be discussed here.

Preventive studies. Four studies in which supplementation was given prophylactically beginning in pregnancy are shown in Table 3.

In Taiwan, pregnant mothers were randomly assigned to receive supplementation or a placebo throughout pregnancy and lactation (Joos et al. 1983). At 8 months of age, the children of supplemented women had better motor development scores but there was no difference in mental scores.

In Bogota, high-risk pregnant mothers were randomly assigned to six groups, four of which will be discussed here (Waber et al. 1981). In one group, the mothers were supplemented during pregnancy and the children for 3 years. In another group, the children were given psychological stimulation for 3 years. The third group received both supplementation and stimulation while the fourth served as controls. Supplementation had beneficial effects on the children's development especially their motor skills at 18 months of age (Mora et al. 1979). At 36 months of age, there were also benefits in language. In contrast, stimulation had a benefit on language and personal social subscales at 18 months of age and only language at 36 months. A significant interaction between supplementation and stimulation was reported at 18 months but not at 36 months.

In Guatemala, all pregnant mothers and young children were offered nutritional supplementation at special centres in four villages (Freeman et al. 1980). Small improvements were found in the cognitive functions of the children who received large amounts of the supplement compared with those who received little. 
Table 3. Preventive supplementation studies in children exposed to undernutrition in developing countries

\begin{tabular}{|c|c|c|c|}
\hline Study & Sample selection & Groups & Concurrent results \\
\hline $\begin{array}{l}\text { Waber et al. } \\
\text { (1981) Bogota, } \\
\text { Colombia }\end{array}$ & $\begin{array}{l}433 \text { high-risk families } \\
\text { randomly assigned to six } \\
\text { groups; treatment from } \\
\text { pregnancy until child was } \\
3 \text { years old }\end{array}$ & $\begin{array}{l}\text { 1. Early supplement } \\
\text { 2. Late supplement } \\
\text { 3. Continual supplement } \\
\text { 4. Stimulation } \\
\text { 5. Stimulation and } \\
\text { supplement } \\
\text { 6. No treatment }\end{array}$ & $\begin{array}{l}\text { Supplement gave small } \\
\text { benefits in development; } \\
\text { moderate increase in } \\
\text { actrivity at } 4 \text { months; } \\
\text { early supplement not } \\
\text { different from late; } \\
\text { stimulation gave small } \\
\text { benefit to language } \\
\text { development }\end{array}$ \\
\hline $\begin{array}{l}\text { Freeman et al. } \\
\text { (1980) Guatemala }\end{array}$ & $\begin{array}{l}\text { Self-selected from four } \\
\text { villages; } 1083 \text { children; } \\
\text { supplement given in } \\
\text { pregnancy, lactation and } \\
\text { up to } 7 \text { years }\end{array}$ & $\begin{array}{l}\text { High supplementation } \\
\text { compared with low } \\
\text { supplementation }\end{array}$ & $\begin{array}{l}\text { Small association between } \\
\text { level of supplement and } \\
\text { cognitive functions on } \\
\text { INCAP preschool battery }\end{array}$ \\
\hline $\begin{array}{l}\text { Joos et al. } \\
\text { (1983) Taiwan }\end{array}$ & $\begin{array}{l}255 \text { pregnant, high-risk } \\
\text { mothers, randomly } \\
\text { assigned to groups; } \\
\text { children not treated }\end{array}$ & $\begin{array}{l}\text { 1. Mothers received } \\
\text { a placebo drink } \\
\text { 2. Supplemented } \\
\text { throughout pregnancy } \\
\text { and lactation }\end{array}$ & $\begin{array}{l}\text { Small benefit in motor } \\
\text { development at } 8 \text { months }\end{array}$ \\
\hline $\begin{array}{l}\text { Chavez \& Martinez } \\
\text { (1982) Mexico }\end{array}$ & $\begin{array}{l}\text { Forty pregnant women in } \\
\text { one village assigned to } \\
\text { two groups separated by } \\
\text { time of birth; } \\
\text { supplementation } \\
\text { throughout pregnancy } \\
\text { and lactation and children } \\
\text { for at least } 3 \text { years }\end{array}$ & $\begin{array}{l}\text { 1. Children born in } \\
1 \text { year supplemented } \\
\text { 2. Children born 1-2 } \\
\text { years previously, } \\
\text { not supplemented }\end{array}$ & $\begin{array}{l}\text { Marked benefit in } \\
\text { development; marked } \\
\text { increase in activity }\end{array}$ \\
\hline
\end{tabular}

INCAP, Institute of Nutrition of Central America and Panama.

In Mexico, Chavez \& Martinez (1982) supplemented children from pregnancy to at least 3 years and found benefits in all subscales of the Gessel development test (Hurwitz, 1984). In addition, the children were observed to be more active and spend less time in their cribs or being carried. The parents' behaviour also became more stimulating towards their children.

Supplementation studies with undernourished children. Three studies with children who were already undernourished are listed in Table 4. In Cali, Colombia undernourished children aged 3 years were randomly assigned to groups of no treatment, supplementation with stimulation or supplementation alone (McKay et al. 1978). Treatment was given for different periods of time. At ages 7 and 8 years, children receiving supplementation alone had no improvement in their performance at tests of cognitive functions. However, those receiving both supplementation and stimulation showed marked benefits which were proportional to the duration of the program. It is difficult to evaluate the apparent lack of effect of supplementation since no dietary intake or anthropometric information was reported

In another Colombian study, the families of both undernourished and adequately nourished pairs of siblings were assigned to supplement or no supplement groups (Mora et al. 1974). After 1 year, the developmental levels of the supplemented undernourished group showed a small, but significant benefit compared with the other groups.

In a recent Jamaican study, children between 9 and 24 months of age with low heights- 
Table 4. Studies of nutritional supplementation in undernourished children

\begin{tabular}{|c|c|c|c|}
\hline Study & Sample selection & Samples & Impact on development \\
\hline $\begin{array}{l}\text { McKay et al. } \\
\text { (1978) Cali, } \\
\text { Colombia }\end{array}$ & $\begin{array}{l}3013 \text {-year-old children } \\
\text { living in two poor, urban } \\
\text { areas, lowest weight and } \\
\text { height; randomly assigned } \\
\text { to seven groups }\end{array}$ & $\begin{array}{l}\text { Four groups each receiving } \\
\text { different periods of } \\
\text { stimulation and } \\
\text { supplementation, three } \\
\text { groups each receiving } \\
\text { different periods of } \\
\text { supplementation }\end{array}$ & $\begin{array}{l}\text { Stimulation with } \\
\text { supplementation had } \\
\text { marked benefit to IQ and } \\
\text { school achievement tests; } \\
\text { effect increased with dura- } \\
\text { tion. Supplementation } \\
\text { alone, no benefit }\end{array}$ \\
\hline $\begin{array}{l}\text { Mora et al. } \\
\text { (1974) Bogota, } \\
\text { Colombia }\end{array}$ & $\begin{array}{l}\text { Ninety-three } \\
\text { undernourished and } \\
\text { ninety-six adequately } \\
\text { nourished sibling pairs, } \\
\text { aged } 6 \text { to } 60 \text { months; } \\
\text { group assignment not } \\
\text { given; treatment for } 1 \\
\text { year }\end{array}$ & $\begin{array}{l}\text { 1. Well nourished } \\
\text { supplemented } \\
\text { 2. Well nourished } \\
\text { unsupplemented } \\
\text { 3. Undernourished } \\
\text { supplemented } \\
\text { 4. Undernourished } \\
\text { unsupplemented }\end{array}$ & $\begin{array}{l}\text { Supplement made small } \\
\text { benefits to development in } \\
\text { undernourished children } \\
\text { only }\end{array}$ \\
\hline $\begin{array}{l}\text { Grantham- } \\
\text { McGregor et al. } \\
(1989 a, b) \text { Jamaica }\end{array}$ & $\begin{array}{l}129 \text { poor urban children } \\
\text { with low height-for-age, } \\
9-24 \text { months, randomly } \\
\text { assigned to four groups; } \\
\text { thirty-two non-stunted } \\
\text { children }\end{array}$ & $\begin{array}{l}\text { 1. Stimulated } \\
\text { 2. Supplemented } \\
\text { 3. Both } \\
\text { 4. Control } \\
\text { 5. Non-stunted }\end{array}$ & $\begin{array}{l}\text { Stimulation, and } \\
\text { supplementation benefited } \\
\text { development; ' both' did } \\
\text { best; no interaction } \\
\text { between treatments }\end{array}$ \\
\hline
\end{tabular}

for-age were randomly assigned to groups which received either supplementation, stimulation, both treatments or none (Grantham-McGregor et al. 1989 b). After 1 year, both stimulation and supplementation produced benefits to their developmental levels. The supplement improved locomotor development mostly. The group which received both treatments showed the greatest benefits but there was no significant interaction between the treatments.

\section{Comments on supplementation studies}

There are many problems with interpreting these studies (Grantham-McGregor, 1987) and only the most important ones will be mentioned. Failure to assign subjects randomly to groups (Freeman et al. 1980; Chavez \& Martinez, 1982) makes it impossible to infer a causal relationship. In the Guatemalan study, the supplement was given by self-selection and this almost certainly introduced a bias. In the Mexican study, groups were separated by time, so that it is not possible to be sure that factors other than the supplement did not produce the changes.

The extra attention focused on the supplemented children might have unplanned benefits. Only one study had a true placebo (Joos et al. 1983), although in the Jamaican study (Grantham-McGregor et al. $1989 \mathrm{~b}$ ) attention was controlled by making an equal number of visits to the control group.

Where the mothers or other family members were supplemented, their behaviour towards the children might have changed and this may have also affected the children's development.

Differences in the subjects' initial age and nutritional status may affect the response. The only study from a developing country with negative findings from supplementation alone began with 3-year-olds (McKay et al. 1978).

In most of the studies very modest increases in dietary intakes were achieved owing to 
substitution of the usual diet and sharing the supplement. Furthermore, in some studies dietary intakes were not reported.

Three studies had robust designs (Joos et al. 1983; Waber et al. 1981; GranthamMcGregor et al. 1989 b). However, in the latter study only preliminary analyses have been conducted, while in the Columbian study there was no attempt to control for extra attention (Waber et al. 1981).

The findings in developing countries were generally consistent in that preventative supplementation produced small concurrent benefits to children's development. There was some indication that motor development was affected first. There is evidence from only two studies that children already undernourished improve with supplementation (Mora et al., 1974 ; Grantham-McGregor et al. 1989 b). In the latter study locomotor development was also the first aspect of development to be affected. Unfortunately, no details were given of the former study.

Only two studies looked for an interaction between stimulation and supplementation (Waber et al. 1981; Grantham-McGregor et al. 1989 b). It was only found in 18-month-old children in the former study. No interaction was found after 1 year's intervention in the Jamaican study.

It would appear that mild to moderate undernutrition has a concurrent detrimental effect on children's development. The size of the effect cannot be deduced from the previously described studies because in general the nutritional status of the supplemented children did not reach normal reference levels, so that small improvements in growth were accompanied by small improvements in development.

\section{Long-term effects of supplementation}

There is very limited evidence of long-term effects from supplementation. Some benefits were reported from supplementation and stimulation in children's school grades in the Cali study (McKay \& McKay, 1983). School achievement and behaviour benefits were also found in children in the first grade in the Mexican study (Chavez \& Martinez, 1981), but it is not clear whether the children were still being supplemented.

Children who were supplemented with or without stimulation in the Bogota study (Herrera \& Super, 1983) were reported to have higher scores in school readiness tests at 7 years of age.

\section{MECHANISM}

The transient behavioural changes which accompany severe malnutrition or concurrent inadequate dietary intake almost certainly have a metabolic basis.

The mechanism linking PEM to long-term developmental deficits is more difficult to explain. There are two main hypotheses. The first is that the transient behavioural changes such as reduced attention, activity and exploration lead to substantial development lags if they occur repeatedly or continue for long periods.

Studies of activity levels in undernourished children have been reviewed recently (Grantham-McGregor et al. 1990). Undernourished children have generally been found to be less active and to explore less than adequately nourished children. However, a temporal sequence whereby reduced activity leads to poor development has not been established. Caretakers of undernourished children may become less responsive to children who are apathetic and this behaviour may, in turn, exacerbate the situation.

Gandour (1990) demonstrated an interaction between activity and environmental stimulation in predicting exploratory competence in adequately nourished 2-year-olds in the USA. We would speculate that there may be an interaction between the child's activity and exploration on one hand and stimulation in the environment on the other, in 
determining developmental levels of undernourished children. Decreased activity may not affect development of children in a stimulating environment but would in a non-stimulating one.

The second hypothesis is that irreversible changes occur in the brain which produce behavioural changes. It has been shown that rats which are undernourished before weaning have persistent changes to the neuroanatomy of the brain (Bedi, 1987). However, although biochemical and structural changes have been found in the brains of severely malnourished children who died, it is not clear if they persist in children who survive (Dickerson et al. 1982).

These hypotheses are not mutally exclusive.

\section{CONCLUSIONS}

There is an increasing amount of evidence that all the nutritional deficiencies reviewed here detrimentally affect children's concurrent mental functions. In the case of I and probably severe PEM in poor environments, long-term effects have also been demonstrated, It is likely that Fe deficiency, and mild to moderate undernutrition, if allowed to persist for long periods may lead to developmental lags which are difficult to reverse. The long-term effects of recurrent short-term food deprivation are unknown.

Considering the high prevalence of these conditions the public health implications are enormous.

Both authors are supported by The Wellcome Trust, UK.

\section{REFERENCES}

Agarwal, D. K., Upadhyay, S. K., Tripathi, A. M. \& Agarwal, K. N. (1987). Nutritional status, physical work capacity and mental function in school children. Nutrition Foundation of India Scientific Report no. 6. New Delhi: Nutrition Foundation of India.

Aukett, M., Parks, Y., Scott, P. \& Wharton, B. (1986). Treatment with iron increases weight gain and psychomotor development. Archives of Disease in Childhood 61, 849-857.

Bames, R. H., Neely, C. S., Kwong, E., Labadan, B. A. \& Frañkova, S. (1968). Post-natal nutritional deprivations as determinants of adult rat behavior toward food, its consumption and utilization. Journal of Nutrition 96, 467-476.

Bartel, P., Griesel, R., Burnett, L., Freiman, I., Rosen, E. \& Geefhuysen, J. (1978). Long-term effects of kwashiorkor on psychomotor development. South African Medical Journal 53, 360-362.

Bautista, A., Barker, P. A., Dunn, J. T., Sanchez, M. \& Kaiser, D. L. (1982). The effects of oral iodized oil on intelligence, thyroid status, and somatic growth in school-age children from an area of endemic goiter. American Journal of Clinical Nutrition 35, 127-134.

Bedi, K. (1987). Lasting neuroanatomical changes following undernutrition. In Early Nutrition and Later Achievement, pp. 1-49 [J. Dobbing, editor]. London: Academic Press.

Benton, D., Brett, V. \& Brain, P. (1987). Glucose improves attention and reaction to frustration in children. Biological Psychology 24, 95-100.

Berglund, G. \& Rabo, E. (1973). A long-term follow-up investigation of patients with hypertrophic pyloric stenosis - with special reference to the physical and mental development. Acta Paediatrica Scandinavica 62, $125-129$.

Birch, H. G., Pineiro, C., Alcalde, E., Toca, T. \& Cravioto, J. (1971). Relation of kwashiorkor in early childhood and intelligence at school age. Pediatric Research 5, 579-585.

Bleichrodt, N., Garcia, I., Rubio, C., Morreale de Escobar, G. \& Ecobar del Rey, F. (1987). Developmental disorders associated with severe iodine deficiency. In The Prevention and Control of Iodine Deficiency Disorders, pp. 65-84 [B. Hetzel, J. Dunn and J. Stanbury, editors]. Amsterdam: Elsevier.

Champakam, S., Srikantia, S. G. \& Gopalan, C. (1968). Kwashiorkor and mental development. American Journal of Clinical Nutrition 21, 844-852.

Chavez, A. \& Martinez, C. (1981). School performance of supplemented and unsupplemented children from a poor rural area. Nutrition in Health and Disease and International Development, pp. 393-402. (A. E. Harper and G. K. Davis, editors.] New York: Alan Liss. 
Chavez, A. \& Martinez, C. (1982). Growing Up In a Developing Community. Guatemala City: Institute of Nutrition in Central America and Panama.

Christiansen, N., Vuori, L., Clement, J., Herrera, M. G., Mora, J. O. \& Ortiz, N. (1977). Malnutrition, social environment and cognitive development of Colombian infants and preschoolers. Nutrition Reports International 16, 93-102.

Chun, F. (1971). Nutrition and education - a study. Journal of the Singapore Pediatric Society 13, 91-96.

Clarke, N., Grantham-McGregor, S. \& Powell, C. (1990). Health and nutrition predictors of school failure in Kingston, Jamaica. Ecology of Food and Nutrition (In the Press.)

Colombo, M., de Andraca, I. \& Lopez, I. (1988). Mental development and stunting. In Linear Growth Retardation in Less Developed Countries, pp. 201-214 [J. Waterlow, editor]. New York: Raven Press.

Conners, C. \& Blouin, A. (1983). Nutritional effects on behavior of children. Journal of Psychiatric Research 17, 193-201.

Connolly, K. J., Pharaoh, P. O. D. \& Hetzel, B. S. (1979). Fetal iodine deficiency and motor performance during childhood. Lancet ii, 1149-1151.

Cravioto, J. \& Arrieta, R. (1979). Stimulation and mental development of malnourished infants. Lancet ii, 899.

Cravioto, J. \& DeLicardie, E. (1972). Environmental correlates of severe clinical malnutrition and language development in survivors from kwashiorkor or marasmus. In Nutrition, the Nervous System and Behavior, Scientific Publication no. 251, pp. 73 94. Washington, DC: Pan American Health Organization.

Cravioto, J., DeLicardie, E. \& Birch, H. (1966). Nutrition, growth and neuro-integrative development: an experimental and ecologic study. Pediatrics 38, 319-372.

Cravioto, J. \& Robles, B. (1965). Evolution of adaptive and motor behavior during rehabilitation from kwashiorkor. American Journal of Ortho-Psychiatry 35, 449-464.

Deinard, A. S., List, A., Lindgren, B., Hunt, J. V. \& Chang, P. N. (1986). Cognitive deficits in iron-deficient and iron-deficient anemic children. Journal of Pediatrics 108, 681-689.

DeMaeyer, E. \& Adiels-Tegman, M. (1985). The prevalence of anaemia in the world. World Health Statistics Quarterly 38, 302316.

Dickerson, J., Merat, A. \& Yusuf, H. (1982). Effects of malnutrition on brain growth and development. In Brain and Behavioural Development, pp. 73-108 [J. Dickerson and H. McGurk, editors]. London: Surrey University Press.

Dickie, N. \& Bender, A. (1982). Breakfast and performance. Human Nutrition: Applied Nutrition 36 A, 46-56.

Dwyer, J. T., Elias, M. F., Warram, J. \& Stare, F. J. (1972). Effects of a school snack program on certain aspects of school performance. Federation Proceedings 31, 718.

Ellis, C. E. \& Hill, D. E. (1975). Growth, intelligence and school performance in children with cystic fibrosis who have had an episode of malnutrition during infancy. Journal of Pediatrics 87, 565-568.

Evans, D., Moodie, A. \& Hansen, J. (1971). Kwashiorkor and intellectual development. South African Medical Journal 45, 1413-1426.

Eysenck, M. (1976). Arousal, learning and memory. Psychological Bulletin 83, 389-404.

Fairchild, M. W., Haas, J. \& Habicht, J.-P. (1989). Iron deficiency and behavior: criteria for testing causality. American Journal of Clinical Nutrition 50, 566-574.

Fierro-Benitez, R., Casar, R., Stanbury, J., Rodriguez, P., Garces, F., Fierro-Renoy, F. \& Estrella, E. (1986). Long-term effects of correction of iodine deficiency on psychomotor development and intellectual development. In Towards the Eradication of Endemic Goiter, Cretinism and Iodine Deficiency, pp. 182-200 [J. Dunn, E. Pretell, C. Daza and F. Viteri, editors]. Washington, DC: Pan American Health Organization.

Florencio, C. (1988). Nutrition, Health and Other Determinants of Academic Achievement and School-related Behavior of Grades One to Six Pupils. Quezan City, Phillipines: University of the Phillipines.

Freeman, H., Klein, R., Townsend, J. \& Lechtig, A. (1980). Nutrition and cognitive development among rural Guatemalan children. American Journal of Public Health 70, 1277-1285.

Galler, J. R., Ramsey, F., Forde, V., Salt, P. \& Archer, E. (1987a). Long-term effects of early kwashiorkor compared with marasmus. II. Intellectual performance. Journal of Pediatrics, Gastroenterology and Nutrition 6 , 847-854.

Galler, J. R., Ramsey, F., Salt, P. \& Archer, E. (1987b). Long-term effects of early kwashiorkor compared with marasmus. III. Fine motor skills. Journal of Pediatrics, Gastroenterology and Nutrition 6, 855-859.

Galler, J. R., Ramsey, F. \& Solimano, G. (1984a). The influence of early malnutrition on subsequent behavioral development. III. Learning disabilities as a sequel to malnutrition. Pediatric Research 18, $309-313$.

Galler, J. R., Ramsey, F., Solimano, G., Kucharski, L. T. \& Harrison, R. (1984b). The influence of early malnutrition on subsequent behavioral development. IV. Soft neurologic signs. Pediatric Research 18, 826-832.

Galler, J. R., Ramsey, F., Solimano, G. \& Lowell, W. (1983a). The influence of early malnutrition on subsequent behavioral development. II. Classroom behavior. Journal of the American Academy of Child Psychiatry 22, 16-22.

Galler, J. R., Ramsey, F., Solimano, G., Lowell, W. \& Mason, E. (1983b). The influence of early malnutrition on subsequent behavioral development. I. Degree of impairment of intellectual performance. Journal of the American Academy of Child Psychiatry 22, 8-15. 
Gandour, M. J. (1990). Activity level as a dimension of temperament in toddlers: its relevance for the organismic specificity hypothesis. Child Development. (In the Press.)

Golden, M. H. N. (1988). The role of individual nutrient deficiencies in growth retardation of children as exemplified by zinc and protein. In Linear Growth Retardation in Less Developed Countries, pp. 143-164 [J. C. Waterlow, editor]. New York: Raven Press.

Gomez, F., Galvan, R., Cravioto, J. \& Frenk, S. (1955). Malnutrition in infancy and childhood with special reference to kwashiorkor. Advances in Pediatrics 7, 131-169.

Graham, G. \& Adrianzen, B. (1979). Status at school of Peruvian children severely malnourished in infancy. In Behavioral Effects of Energy and Protein Deficits, pp. 185-194. [J. Brozek, editor]. Washington, DC: US Department of Health, Education and Welfare.

Grant, J. (1990). The State of the World's Children. New York: Oxford University Press.

Grantham-McGregor, S. (1982). The relationship between developmental level and different types of malnutrition in children. Human Nutrition: Clinical Nutrition 36C, 319.320.

Grantham-McGregor, S. (1984). Chronic undernutrition and cognitive abilities. Human Nutrition: Clinical Nutrition 38C, 83-94.

Grantham-McGregor, S. (1987). Field studies in early nutrition and later achievement. In Early Nutrition and Later Achievements, pp. 128-174 [J. Dobbing, editor]. London: Academic Press.

Grantham-McGregor, S., Meeks Gardner, J., Walker, S. \& Powell, C. (1990). The relationship between undernutrition, activity levels and development in young children. In Activity, Energy Expenditure and Energy Requirements of Infants and Children. [B. Schurch and N. Scrimshaw, editors]. Switzerland: Nestlé Foundation. (In the Press.)

Grantham-McGregor, S., Powell, C. \& Fletcher, P. (1989a). Stunting, an episode of severe malnutrition and mental development in young children. European Journal of Clinical Nutrition 43, 403-409.

Grantham-McGregor, S., Powell, C. \& Walker, S. (1989b). Nutritional supplements, stunting and child development. Lancet ii, $809-810$.

Grantham-McGregor, S., Schofield, W. \& Powell, C. (1987). Development of severely malnourished children who received psychosocial stimulation: six year follow-up. Pediatrics 79, 247-254.

Hebb, D. O. (1972). Textbook of Psychology, 3rd ed. Philadelphia, PA: Saunders.

Herrera, M. \& Super, C. (1983). School Performance and Physical Growth of Underprivileged Children: Results of the Bogota Project at Seven Years. Report to World Bank. Cambridge, MA : Harvard School of Public Health.

Hertzig, M., Birch, H., Richardson, S. \& Tizard, J. (1972). Intellectual levels of school children severely malnourished during the first two years of life. Pediatrics $49,814-824$.

Hetzel, B. (1983). Iodine deficiency disorders (IDD) and their eradication. Lancet i, 1126-1129.

Hetzel, B. (1987). An overview of the prevention and control of iodine deficiency disorders. In The Prevention and Control of Iodine Deficiency Disorders, pp. 7-31 [B. Hetzel, J. Dunn and J. Stanbury, editors]. Amsterdam: Elsevier.

Heywood, A., Oppenheimer, S., Heywood, P. \& Jolley, D. (1989). Behavioral effects of iron supplementation in infants in Madang. Papua New Guinea. American Journal of Clinical Nutrition 50, 630-640.

Hicks, L., Langham, R. \& Takenaka, J. (1982). Cognitive and health measures following early nutritional supplementation. American Journal of Public Health 72, 1110-1118.

Hoorweg, J. \& Stanfield, J. (1976). The effects of protein-energy malnutrition in early childhood on intellectual and motor abilities in later childhood and adolescence. Developmental Medicine and Child Neurology 18, 330-350.

Horowitz, F. D. (1989). Using developmental theory to guide the search for the effects of biological risk factors on the development of children. American Journal of Clinical Nutrition 50, 589-597.

Hurwitz, I. (1984). Psychometric methods. In Malnutrition and Behavior: Critical Assessment of Key Issues pp. 164-176. [J. Brozek and B. Schurch, editors]. Lausanne, Switzerland: Nestlé Foundation.

Jamison, D. (1986). Child malnutrition and school performance in China. Journal of Development Economics 20 , 299. 309.

Johnston, F., Low, S., de Baessa, Y. \& McVean, R. (1987). Interaction of nutrition and socio-economic status as determinants of cognitive development in disadvantaged urban Guatemalan children. American Journal of Physical Anthropology 73, 501-506.

Joos, S., Pollit, E., Mueller, W. \& Albright, D. (1983). The Bacon Chow Study: maternal nutritional supplementation and infant behavioral development. Child Development 54, 669-676.

Keister, M. E. (1950). Relation of mid-morning feeding to behavior of nursery school children. Journal of the American Dietetic Association 26, 25-29.

Klein, P., Forbes, G. \& Nader, P. (1975). Effects of starvation in infancy (pyloric plenosis) on subsequent learning abilities. Journal of Pediatrics 87, 8-15.

Kruesi, M. J. R. \& Rapoport, J. L. (1986). Diet and human behavior: how much do they affect each other? Annual Review of Nutrition 6, 113130.

Laird, D., Levitan, M. \& Wilson, V. (1931). Nervousness in school children as related to hunger and diet. Medical Journal Records 134, 494-499. 
Lasky, R., Klein, R., Yarbrough, C., Engle, P., Lechtig, A. \& Martorell, R. (1981). The relationship between physical growth and infant behavioral development in rural Guatemala. Child Development 52, $219-226$.

Levinger, B. (1986). Schoolfeeding programs in developing countries: an analysis of actual and potential impact. AID Evaluation Special Study no. 30. Washington, DC: USAID.

Levitsky, D. (1979). Malnutrition and the hunger to learn. In Malnutrition, Environment and Behavior, pp. 161-179. [D. Levitsky, editor.] Ithaca, NY: Cornell University Press.

Levitsky, D. A. \& Barnes, R. H. (1970). Effect of early malnutrition on the reaction of adult rats to aversive stimuli. Nature 225, 468-469.

Lloyd-Still, J., Hurtwitz, I., Wolf, P. \& Shwachman, H. (1974). Intellectual development after severe malnutrition in infancy. Pediatrics 54, 306-311.

Lozoff, B., Brittenham, G. M., Viteri, F. E., Wolf, A. W. \& Urrutia, J. J. (1982). The effects of short-term oral iron therapy on developmental deficits in iron-deficient anemic infants. Journal of Pediatrics 100, 351-357.

Lozoff, B., Brittenham, G., Wolf, A., McClish, D., Kuhnert, P., Jiminez, E., Jiminez, R., Mora, L., Gomez, I. \& Kruashkoph, D. (1987). Iron deficiency anemia and iron therapy effects on infant developmental test performance. Pediatrics 79, 981-995.

McKay, A. \& McKay, H. (1983). Primary school progress after preschool experience: troublesome issues in the conduct of follow-up research and findings from Cali, Colombia Study. In Preventing School Failure: The Relationship Between Preschool and Primary Education, pp. 32-42 [K. King and R. Meyers, editors]. Ottawa: International Development Research Center.

McKay, H., Sinisterra, L., McKay, A., Gomez, H. \& Lloreda, P. (1978). Improving cognitive ability in chronically deprived children. Science 200, 270-278.

McLaren, D., Yatkin, U., Kanawati, A., Sabbagh, S. \& Kadi, Z. (1973). The subsequent mental and physical development of rehabilitated marasmic infants. Journal of Mental Deficiency Research 17, 273-281.

Meyers, A., Sampson, A., Weitzman, M., Rogers, B. \& Kayne, H. (1989). School breakfast program and school performance. American Journal of Diseases of Children 143, 1234-I 239.

Monckeberg. F. (1972). Malnutrition and mental capacity. Nutrition, the Nervous System and Behavior. PAHO Scientific Publication no 251, pp. 48-54. Washington, DC: Pan American Health Organization.

Monckeberg, F. (1979). Recovery of severely malnourished infants: effect of early sensory-affective stimulation. In Behavioral Effects of Energy and Protein Deficits, DHEW Publication no. 79-1906, pp. 121-230. [J. Brozek and B. Schurch, editors]. Washington, DC: US Department of Health, Education and Welfare.

Moock, P. \& Leslie, J. (1986). Childhood malnutrition and schooling in the Terai region of Nepal. Journal of Development Economics 20, 33-52.

Moodie, A., Bowie, M., Mann, M. \& Hansen, J. (1980). A prospective 15-year follow-up study of kwashiorkor patients. Part II. Social circumstances, educational attainment and social adjustment. South African Medical Journal 58, 677-681.

Mora, J. A., Amezquita, A., Castro, L., Christiansen, N., Clement-Murphy, J., Cobos, L. F., Cremer, H. D., Dragastin, S., Elias, M. F., Franklin, D., Herrera, M. G., Ortiz, N., Pardo, F., de Paredes, B., Ramos, C., Riley, R., Rodriguez, H., Vuori-Christiansen, L., Wagner, M. \& Stare, F. J. (1974). Nutrition, health and social factors related to intellectual performance. World Review of Nutrition and Dietetics 19, 205-236.

Mora, J., Clement, J., Christiansen, N., Ortiz, N., Vuori, L. \& Wagner, M. (1979). Nutritional supplementation, early stimulation and child development. In: Behavioral Effects of Energy and Protein Deficits, DHEW Publication no. 79-1906, pp. 225-269: [J. Brozek and B. Schurch, editors]. Washington, DC: US Department of Health, Education and Welfare.

Nwuga, V.C. B. (1977). Effect of severe kwashiorkor on intellectual development among Nigerian children. American Journal of Clinical Nutrition 30, 1423-1430.

Oski, F. A. \& Honig, A. S. (1978). The effects of therapy on the developmental scores of iron-deficient infants. Journal of Pediatrics 92, 21-25.

Osofsky, H. (1975). Relationships between pre-natal medical and nutritional measures, pregnancy outcome, and early infant development in an urban poverty setting. I. The role of nutritional intake. American Journal of Obstetrics and Gynecology 123, 632-690.

Pencharz, P., Heller, A., Higgins, A., Strawbridge, J., Rush, D. \& Pless, B. (1983). Effects of nutritional services to pregnant mothers on the school performance of treated and untreated children. Nutrition Research 3 , 795-803.

Pereira, S. M., Sundararaj, R. \& Begum, A. (1979). Physical growth and neuro-integrative performance of survivors of protein-energy malnutrition. British Journal of Nutrition 42, 165-171.

Pollitt, E. (1987). A critical view of three decades of research on the effects of chronic energy malnutrition on behavioral development. In Chronic Energy Deficiency: Consequences and Related Issues, pp. 77-93 [B. Schurch and N. Scrimshaw, editors]. Switzerland: Nestlé Foundation.

Pollitt, E. (1989). Infancy. Mental and motor development. Comments. American Journal of Clinical Nutrition S0, 662-664.

Pollitt, E., Hathirat, P., Kotchabhakdi, N. J., Missell, L. \& Valyasevi, A. (1989 b). Iron deficiency and educational achievement in Thailand. American Journal of Clinical Nutrition 50, 687-697. 
Pollitt, E., Leibel, R. L. \& Greenfield, D. (1981). Brief fasting, stress, and cognition in children. American Journal of Clinical Nutrition 34, 1526-1533.

Pollitt, E., Leibel, R. L. \& Greenfield, D. (1983a). Iron deficiency and cognitive test performance in preschool children. Nutrition and Behavior 1, 137-146.

Pollitt, E., Lewis, N., Garcia, C. \& Shulman, R. (1983b). Fasting and cognitive function. Journal of Psychiatric Research 17, 169-174.

Pollitt, E., Saco-Pollitt, C., Leibel, R. L. \& Viteri, F. E. (1986). Iron deficiency and behavioral development in infants and preschool children. American Journal of Clinical Nutrition 43, 555-565.

Pollitt, E., Soemantri, A. G., Yunis, F. \& Scrimshaw, N. S. (1985). Cognitive effects of iron-deficiency anaemia. Lancet i, 158.

Pollitt, E. \& Thomson, C. (1977). Protein-calorie malnutrition and behavior. A view from psychology. In Nutrition and the Brain, vol. 2, pp. 261-306 [R. Wurtman and J. Wurtman, editors]. New York: Raven Press.

Pollitt, E., Haas, J. \& Levitsky, D. (editors) (1989a). International conference on iron deficiency and behavioral development. American Journal of Clinical Nutrition S0, 565-705.

Popkin, B. \& Lim-Ybanez, M. (1982). Nutrition and school achievement. Social Science and Medicine 16, 53-61.

Powell, C. \& Grantham-McGregor, S. (1980). The associations between nutritional status, school achievement and school attendance in 12-year-old children at a Jamaican school. West Indian Medical Journal 29, 247-253.

Powell, C. A. \& Grantham-MeGregor, S. (1985). The ecology of nutritional status and development in young children in Kingston, Jamaica. American Journal of Clinical Nutrition 41, 1322-1331.

Powell, C. A., Grantham-McGregor, S. \& Elston, M. (1983). An evaluation of giving the Jamaican government schoolmeal to a class of children. Human Nutrition: Clinical Nutrition 37C, 381-388.

Richardson, S. (1974). The background histories of schoolchildren severely malnourished in infancy. Advances in Pediatrics 21, 167-195.

Richardson, S., Birch, H. \& Hertzig, M. (1973). School performance of children who were severely malnourished in infancy. American Journal of Mental Deficiency 77, 623-632.

Rush, D. (1984). The behavioral consequence of protein-energy deprivation and supplementation in early life: an epidemiological perspective. In Human Nutrition: A Comprehensive Treatise, pp. 119-154 [J. Galler, editor]. New York: Plenum Press.

Rush, D., Stein, Z. \& Susser, M. (1980). A randomized controlled trial of pre-natal nutritional supplementation in New York City. Pediatrics 65, 683-697.

Scrimshaw, N. S. (1984). Functional consequences of iron deficiency in human populations. Journal of Nutritional Science and Vitaminology 30, 47-63.

Seshadri, S. \& Gopaldas, T. (1989). Impact of iron supplementation on cognitive functions in preschool and school-aged children: the Indian experience. American Journal of Clinical Nutrition 50, 675-686.

Sigman, M., Neuman, C. \& Jansen, A. (1990). Cognitive abilities of Kenyan children in relation to nutrition, family characteristics and education. Child Development (In the Press.)

Simeon, D. T. \& Grantham-McGregor, S. (1989). Effects of missing breakfast on the cognitive functions of school children of differing nutritional status. American Journal of Clinical Nutrition 49, 646-653.

Smart, J. L. \& Dobbing, J. (1977). Increased thirst and hunger in adult rats undernourished as infants: an alternative explanation. British Journal of Nutrition 37, 421-430.

Soemantri, A. G. (1989). Preliminary findings on iron supplementation and learning achievement of rural Indonesian children. American Journal of Clinical Nutrition 50, 698-702.

Soemantri, A. G., Pollitt, E. \& Kim, I. (1985). Iron deficiency anemia and educational achievement. American Journal of Clinical Nutrition 42, $1221 \cdot 1228$.

Soewondo, S., Husaini, M. \& Pollitt, E. (1989). Effects of iron deficiency on attention and learning processes in preschool children: Bandung, Indonesia. American Journal of Clinical Nutrition 50, 667-674.

Stanbury, J. (1987). Iodine deficiency disorders: introduction and general aspects. In The Prevention and Control of Iodine Deficiency Disorders, pp. 35-47 [B. Hetzel, J. Dunn and J. Stanbury, editors]. Amsterdam: Elsevier.

Tuttle, W. W., Daum, K., Larsen, R., Salzano, J. \& Roloff, L. (1954). Effect on school boys of omitting breakfast. Physiologic responses, attitudes, and scholastic attainments. Journal of the American Dietetic Association 30. 674-677.

Upadhyay, S., Agarwal, D., Agarwal, K., Srivastava, K. \& Adhikari, G. (1988). Brief fasting and cognitive functions in rural school children. Indian Pediatrics 25, 288-289.

Valman, H. (1974). Intelligence after malnutrition caused by neonatal resection of ileum. Lancet i, 425-427.

Waber, D. P., Vuori-Christiansen, L., Ortiz, N., Clement, J. R., Christiansen, N. E., Mora, J. O., Reed, R. B. \& Herrera, M. G. (1981). Nutritional supplementation, maternal education, and cognitive development of infants at risk of malnutrition. American Journal of Clinical Nutrition 34, 807-813.

Walter, T., de Andraca, I., Chadud, P. \& Perales, C. (1989). Iron deficiency anaemia : adverse effects on infant psychomotor development. Pediatrics 84, 7-17. 
Walter, T., Kovalskys, J. \& Stekel, A. (1983). Effect of mild iron deficiency on infant mental development scores. Journal of Pediatrics 102, 519522.

Waterlow, J. (1976). Classification and definition of protein energy malnutrition. In Nutrition in Preventative Medicine, WHO Monograph Series no. 62, pp. 530-555 [G. Beaton and J. Bengoa, editors]. Geneva: World Health Organization.

Wellcome Trust Working Party (1970). Classification of infantile malnutrition. Lancet ï, 302.

Wilson, A. (1981). Longitudinal analysis of diet, physical growth, verbal development, and school performance. In Malnourished Children of the Rural Poor, pp. 39-81 [J. Balderston, A. Wilson, M. Freire and M. Simonen, editors]. Boston, MA: Auburn House Publishing Company.

Winick, M., Meyer, K. K. \& Harris, R. C. (1975). Malnutrition and environmental enrichment by early adoption. Development of adopted Korean children differing greatly in early nutritional status is examined. Science 190, 1173-1175.

Wurtman, R. J. (1986). Ways that foods can affect the brain. Nutrition Reviews 44, Suppl. 2-6.

Yatkin, V. \& McLaren, D. (1970). The behavioural development of infants recovering from severe malnutrition. Journal of Mental Deficiency Research 14, 25-32. 